\title{
PENGARUH CURRENT RATIO, DEBT EQUITY RATIO, TOTAL ASSET TURNOVER TERHADAP PRICE EARNING RATIO
}

\author{
Rita Purnama Sari ${ }^{1}$, \\ Sri Hermuningsih ${ }^{2}$, \\ Agus Dwi Cahya ${ }^{3}$ \\ ${ }^{1}$ Fakultas Ekonomi, Universitas Sarjanawiyata Tamansiswa \\ Email : rittapurnama1@gmail.com \\ ${ }^{2}$ Fakultas Ekonomi, Universitas Sarjanawiyata Tamansiswa \\ Email : hermun_feust@yahoo.co.id \\ ${ }^{3}$ Fakultas Ekonomi, Universitas Sarjanawiyata Tamansiswa \\ Email : agusdc@ustjogja.ac.id
}

\begin{abstract}
Dalam berinvestasi saham memiliki risiko yang cukup tinggi, maka ketika berinvestasi investor harus dapat menganalisis dengan baik agar bisa mendapatkan keuntungan yang baik, yaitu dengan menggunakan analisis fundamental dengan pendekatan Price Earning Ratio. Penelitian ini bertujuan untuk menguji pengaruh current ratio, debt to equity ratio, dan total asset turnover terhadap price earning ratio pada perusahaan manufaktur yang terdaftar dalam indeks LQ 45 periode 2015-2019 baik secara parsial maupun secara simultan. Populasi dalam penelitian ini yaitu perusahaan yang pernah masuk dalam Indeks LQ 45. Teknik untuk pengambilan sampel menggunakan purposive sampling. Hasil penelitian menunjukkan bahwa variabel current ratio berpengaruh positif dan signifikan terhadap price earning ratio, variabel debt to equity ratio berpengaruh positif dan signifikan terhadap price earning ratio, variabel total asset turnover tidak berpengaruh terhadap price earning ratio. Serta secara simultan variabel current ratio, debt to equity ratio, dan total asset turnover berpengaruh signifikan terhadap price earning ratio.
\end{abstract}

Keywords: current ratio, debt to equity ratio, total asset turnover, price earning ratio.

\section{PENDAHULUAN}

Dunia usaha semakin berkembang pesat, apalagi pada suatu perusahaan yang semakin terdorong untuk meningkatan efisiensi dan daya saingnya. Dunia usaha setiap perusahaan memiliki tujuan untuk memperoleh laba, untuk mencapainya maka setiap perusahaan harus mengoptimalkan dan memanfaatkan potensi yang dimilikinya dengan baik, sehingga akan membuat nilai perusahaannya tinggi. Nilai perusahaan yang tinggi dapat menaikkan kesejahteraan bagi perusahaan, setiap perusahaan pasti akan berusaha untuk memaksimalkan nilai perusahaannya. Penilaian kinerja perusahaan ialah salah satu aspek yang penting untuk perusahaan dikarenakan penilaian tersebut digunakan sebagai dasar untuk menyusun imbalan atau hasil suatu perusahaan, dimana itu dapat mempengaruhi pengambilan keputusan dalam perusahaan dan memberikan informassi yang berguna untuk membuat keputusan yang penting. Semakin tinggi kinerja suatu perusahaan yang biasanya diproyeksikan dengan rasio keuangan, maka semakin tinggi pula nilai perusahaan tersebut. Perusahaan bisanya menggunakan rasio keuangan untuk mengukur nilai atau kinerja suatu perusahaan, atau dengan melihat laba pada suatu perusahaan yang mana merupakan komponen dalam menciptakan nilai perusahaan yang menunjukkan prospek perusahaan di masa mendatang (Sihaloho, 2020).

Perusahaan meningkatkan labanya dengan cara berinvestasi pada pasar modal. Bentuk investasi yang paling umum adalah saham, investasi saham memiliki beberapa risiko dan sulit untuk diprediksi kedepannya oleh para investor (Haryani \& Priantinah, 2018). Peranan pasar modal untuk media berinvestasi dapat dilihat dari kenaikan volume atai nilai transaksi perdagangan, perdagangan di pasar modal yang semakin berkembang dikarenakan oleh semakin banyaknya perusahaan yang go public sehingga jenis saham yang ditawarkan pun juga semakin beragam (Oktaviasari, 2017).

Menurut Hartono dalam (Oktaviasari, 2017) terdapat dua alat analisis yang dapat digunakan untuk investor atau calon investor dalam melakukan analisis investasi bentuk saham yaitu dengan analisis fundamental dan analisis teknis. Analisis fundamental menggunakan data fundamental yakni data yang berasal dari keuangan perusahaan sedangkan analisis teknis adalah data pasar saham untuk menentukan nilai saham. Analisis teknis digunakan praktisi untuk menentukan harga saham, sedangkan analisis fundamental digunakan oleh para akademisi. Analisis fundamental memiliki dua pendekatan 
untuk meghitung nilai saham, yaitu dengan pendekatan sekarang (present value approach) dan pendekatan rasio harga (price earning ratio).

Menurut Priansyah dalam (Batubara, Astuti, \& Ramadani, 2019) salah satu analisis fundamental yang dapat digunakan untuk menilai kewajaran harga saham adalah price earning ratio karena cukup mudah untuk dipahami oleh para investor. Price earning ratio digunakan untuk memprediksi kemampuan perusahaan dalam menghasilkan laba di masa mendatang oleh para investor. Perusahaan dengan tingkat pertumbuhan yang tinggi biasanya memiliki price earning ratio yang tinggi dan sebaliknya perusahaan yang memiliki tingkat pertumbuhan yang rendah biasanya memiliki price earning ratio yang rendah pula. Investor biasanya melihat PER untuk mengidentifikasi harga saham yang undervalued atau overvalued sehingga investor bisa mengambil keputusan untuk berinvestasi yaitu dengan membeli sahan yang undervalued dan menjualnya disaat overvalued (Oktaviasari, 2017). Menggunakna PER dalam analisa saham dikarenakan PER mempermudah investor dalam menilai prospek saham kedepannya, PER memudahkan investor dalam membandingkan perusahaanperusahaan di dalam satu industri (Sijabat, 2018).

Current ratio merupakan salah satu rasio likuiditas yang menunjukkan kemampuan perusahaan dalam memenuhi kewajiban lancarnya dengan menggunakan aset lancarnya. Debt to equity ratio merupakan bagian dari rasio solvabilitas yang menunjukkan besarnya aktiva yang sumber dananya dari hutang. DER digunakan untuk menilai hutang dengan ekuitas melalui perbandingan total hutang dibagi dengan seluruh ekuitas. Total asset turnover merupakan bagian dari rasio aktivitas yang digunakan untuk mengukur seberapa efektif perusahaan menggunakan sumber dayanya (Sihaloho, 2020).

Berdasarkan uraian beberapa rasio tersebut, menurut beberapa peneliti terdahulu seperti (Susanti, Qomari, \& Negoro, 2017) current ratio memiliki pengaruh yang signifikan terhadap price earning ratio, namun menurut (Batubara et al., 2019) current ratio tidak berpegaruh yang signifikan terhadap price earning ratio. Selanjutnya menurut (Susanti et al., 2017) debt to equity ratio memiliki pengaruh yang signifikan terhadap price earning ratio dan menurut (Wahyuni, Susanto, \& Asakdiyah, 2020) debt to equity ratio memiliki pengaruh negatif dan tidak signifikan terhadap price earning ratio. Selanjutnya menurut (Sihaloho, 2020) TATO memiliki pengaruh yang signifikan terhadap price earning ratio sedangkan menurut (Susanti et al., 2017) TATO tidak memiliki pengaruh terhadap price earning ratio.

Penelitian ini menggunakan laporan keuangan perusahaan manufaktur yang terdaftar dalam indeks LQ 45, yang mana indeks tersebut merupakan salah satu indeks dari 34 indeks yang dikeluarkan oleh Bursa Efek Indonesia. Perusahaan yang masuk dalam indeks LQ 45 merupakan perusahaan yang lebih banyak diminati oleh para investor karena LQ 45 menjadi patokan naik turunnya sahan yang ada di Bursa Efek Indonesia (Yulia, 2016).

Berdasarkan penelitian terdahulu yang menunjukkan adaknya inkonsistensi penelitian serta untuk memperkuat teori dan hasil penelitian sebelumnya maka peneliti tertarik untuk meneliti masalah ini yaitu tentang pengaruh current ratio, debt to equity ratio, dan total asset turnover terhadap price earning ratio pada perusahaan manufaktur yang terdaftar dalam indeks LQ 45 periode 2015-2019. Tujuan dari penelitian ini adalah untuk mengetahui dan menganalisis pengaruh current ratio, debt to equity ratio, dan total asset turnover terhadap price earning ratio secara parsial maupun secara simultan, pada perusahaan manufaktur yang terdaftar dalam indeks LQ 45 periode 2015-2019.

\section{KAJIAN PUSTAKA DAN PEGEMBANGAN HIPOTESIS}

\section{Laporan Keuangan}

Menurut Kasmir (2014) dalam Susanti et al. (2017) laporan keuangan menunjukkan kondisi keuangan perusahaan pada saat ini atau pada suatu periode tertentu. Laporan keuangan menujukkan keadaan finansial suatu perusahaan, dimana memperlihatkan nilai aktiva, utang, modal, laba rugi pada suatu periode tertentu, biasanya meliputi periode satu tahun. Laporan keuangan digunakan utuk memberikan informasi salah satu nya untuk para investor tetntang kondisi suatu perusahaan.

\section{Rasio Keuangan}

Rasio keuangan merupakan kegiatan membandingkan angka-angka yang ada dalam laporan keuangan dengan cara membagi satu angka dengan angka yang lainnya. Jadi rasio keuangan adalah perbandingan antara angka-angka yang terdapat dalam laporan keuangan. Rasio keuangan digunakan untuk menilai kondisi keuangan dan kinerja pada suatu perusahaan. Dari hasil rasio keuangan ini maka akan terlihat kondisi kesehatan pada perusahaan yang bersangkutan (Diana, 2019). 


\section{Price Earning Ratio}

Price Earning Ratio (PER) merupakan salah satu pendekatan yang digunakan oleh analis sekuritas dan investor dalam penilaian saham di pasar modal. PER menggambarkan apresiasi pasar terhadap kemampuan perusahaan dalam menghasilkan laba. Rasio pendapatan harga yang rendah merupakan ketidakmampuan untuk meciptakan nilai dan menunjukkan kinerja yang buruk (Houmes \& Chira, 2015). Para investor biasanya lebih menyukai price earning ratio untuk digunakan dalam mengidentifikasi harga saham yang undervalued atau overvalued sehingga investor dapat mengambil keputusan dalam menghadapi fluktuasi harga saham yaitu untuk membelinya pada saat undervalue dan menjualnya saat overvalue. Namun tingkat dari PER dapat dipengaruhi oleh beberapa faktor, seperti kemampuan perusahaan dalam melunasi hutangnya, dengan tingkat efisiensi dan efektifitas kegiatan operasional perusahaan, dan kondisi eksternal lainnya (Susanti et al., 2017).

\section{Current Ratio}

Current ratio menunjukkan kemampuan perusahaan dalam memenuhi kewajiban jangka pendek atau hutang yang segera jatuh tempo pada saat ditagih. Dengan kata lain seberapa banyak aktiva lancar menutupi kewajiban jangka pendek yang segera jatuh tempo (Wahyuni et al., 2020). Menggunakan rasio lancar ini yaitu lebih relevan dan akurat karena datanya tersedia dan mudah untuk dipahami dan dihitung. Semakin tinggi rasio ini berarti semakin besar pula kemampuan perusahaan untuk memenuhi kewajiban jangka pendek, perusahaan yang memiliki rasio likuiditas tinggi akan diminati oleh investor sehingga berimbas pada harga saham yang akan cenderung naik karena tingginya permintaan (Aulia, 2013).

\section{Debt to Equity Ratio}

Debt to equity ratio digunakan untuk mengukur kemampuan perusahaan dalam melunasi seluruh hutangnya dengan menggunakan modal yang ada. Rasio ini juga menunjukkan struktur modal yang dimiliki perusahaan yang terdiri atas hutang dan ekuitas (Wahyuni et al., 2020). Menurut Fahmi (2013) dalam (Mulyani \& Pitaloka, 2017) debt to equity ratio berguna untuk mengetahui jumlah dana yang disediakan peminjam (kreditor) dengan pemilik perusahaan. Rasio DER akan memberikan arti yang berbeda bagi kreditor dan perusahaan. Bagi bank (kreditor), semakin besar rasio ini akan semakin tidak menguntungkan karena semakin besar resiko yang ditanggung atas kegagalan yang mungkin terjadi di perusahaan.

\section{Total Asset Turnover}

Total asset turnover mengukur efektivitas penggunaan dana pada seluruh aktiva dalam menghasilkan penjualan. Semakin tinggi rasio ini maka semakin baik perusahaan tersebut. Total asset turnover yang semakin besar menunjukkan nilai penjualannya semakin besar, penggunaan asetnya yang semakin efisien dan harapan untuk memperoleh laba pun semakin besar sehingga berimbas pada PER yang akan tinggi pula (Mendra, 2016).

\section{Pengembangan Hipotesis}

\section{Pengaruh current ratio terhadap price earning ratio}

Semakin besar current ratio mencerminkan likuiditas perusahaan semakin tinggi, karena perusahaan memiliki kemampuan membayar yang besar sehingga mampu memenuhi semua kewajiban finansialnya. Dengan semakin meningkatnya likuiditas pada perusahaan, ini berpeluang meningkatkan earning atau pendapatan laba perusahaan, sehingga nilai PER semakin tinggi. Berdasarkan penelitian Supriati (2018) yang menunjukkan pengaruh likuiditas yang diproksikan dengan current ratio terhadap price earning ratio, penelitian tersebut menghasilkan likuiditas berpengaruh dan signifikan terhadap price earning ratio.

$\mathrm{H}_{1}$ : current ratio berpengaruh positif dan signifikan terhadap price earning ratio.

\section{Pengaruh debt to equity ratio terhadap price earning ratio}

Semakin besar debt to equity ratio menunjukkan bahwa semakin besar struktur modal yang berasal dari hutang semakin besar untuk mendanai ekuitas yang ada. Semakin besar DER menunjukkan semakin rendah solvabilitas perusahaan, yang mana kreditor memandang semakin besar rasio ini akan semakin tidak menguntungkan karena akan semakin besar resiko yang ditanggung atas kegagalan yang mungkin terjadi Adanya risiko yang tinggi menyebabkan investasi pada suatu saham akan kurang menarik bagi para investor . akibatnya harga saham akan turun sehingga PER juga akan turun. Dengan demikian diduga terjadi pengaruh negatif DER terhadap price earning ratio. Berdasarkan penelitian 
dari Handayani (2018) yang menunjukkan variabel DER berpengaruh secara signifikan dan negatif terhadap price earning ratio.

$\mathrm{H}_{2}$ : debt to equity ratio berpengaruh negatif dan signifikan terhadap price earning ratio

\section{Pengaruh total asset turnover terhadap price earning ratio}

Total asset turnover menunjukkan tingkat efisiensi penggunaan seluruh aktiva perusahaan dalam menghasilkan penjualan. Perputaran aktiva yang semakin tinggi dalam perusahaan nantinya akan memperlancar perusahaan dalam memperoleh laba untuk memenuhi kewajibannya yan ditunjukkan dari bagian modal sendiri yang digunakan untuk membayar seluruh kewajiban sehingga perusahaan mampu meningkatkan harga sahamnya. Nilai TATO yang positif menunjukkan bahwa penjualan yang diterima perusahaan dari penggunaan total aktivanya memberikan efek peningkatan nilai bagi PER. Berdasarkan penelitian dari Famiah (2016) yang menunjukkan bahwa total asset turnover berpengaruh signifikan terhadap price earning ratio berhasil melakukan efisiensi perputaran aset yang terjadi di dalam perusahaan yang nantinya akan membantu perusahaan dalam memperoleh laba.

$\mathrm{H}_{3}$ : total asset turnover berpegaruh positif dan signifikan terhadap price earning ratio

\section{Pengaruh current ratio, debt to equity ratio, dan total asset turnover terhadap price earning ratio}

Dalam penelitian dari Susanti et al. (2017) dengan judul pegaruh current ratio, debt to equity ratio, dan total asset turnover terhadap price earning ratio pada perusahaan PT. Suparma Tbk menghasilkan signifikansi uji $\mathrm{F}$ yang diperoleh sebesar 0,042 > 0,05 yang artinya current ratio, debt to equity ratio, dan total asset turnover secara bersama-sama memiliki pengaruh signifikan terhadap price earning ratio.

$\mathrm{H}_{4}$ : current ratio, debt to equity ratio, dan total asset turnover berpengaruh secara simultas terhadap price earning ratio.

\section{METODE PENELITIAN}

Penelitian ini yaitu bersifat penelitian kuantitatif, yang mana disajikan dalam bentuk data/tabel dengan memfokuskan pada laporan keuangan khususnya pada laporan tentang current ratio, debt to equity ratio, total asset turnover, dan price earning ratio. Populasi dalam penelitian ini yaitu perusahaan yang pernah masuk dalam indeks LQ 45 selama 2015-2019 dengan sampel sebanyak 8 perusahaan, yang diperoleh menggunakan teknik purposive sampling yaitu pengambilan sampel dengan kriteria tertentu. Kriteria pengambilan sampel dalam penelitian ini adalah:

1. Perusahaan yang secara berturut-turut terdaftar di Indeks LQ 45 tahun 2015-2019.

2. Perusahaan yang masuk dalam LQ 45 yang mempublikasikan laporan keuangan tahunan pada tahun 2015-2019 sesuai dengan data yang diperlukan dalam variable penelitian.

Data yang digunakan dalam penelitian ini adalah data sekunder yang sumber datanya diperoleh dari laporan-laporan keuangan dan laporan beberapa rasio keuangan pada masing-masing perusahaan di indeks LQ 45 periode 2015-2019, menggunakan LQ 45 dikarenakan banyak dilirik oleh para investor, dengan data atau laporan diperoleh dari www.idx.co.id. Metode pengumpulan data dalam penelitian ini dilakukan dengan cara non participant observation atau sekunder yaitu dengan mengkasi buku-buku, jurnal, dan makalah untuk landasan teoritis serta dengan laporan keuangan tersebut (Affinanda \& Yuyetta, 2015).

\section{Definisi Operasional Variabel}

Price earning ratio ini dapat dihitung dengan membagi harga saham perusaahaan dengan earning per share. Menurut Fahmi (2014) dalam Susanti et al. (2017) rumus price earning ratio:

$$
\text { PER }=\frac{\text { harga saham }}{\text { earning per share }}
$$

Current ratio yaitu perbandingan antara aktiva lancar dengan hutang lancar (Handayani, 2018), rumus Current Ratio:

$$
C R=\frac{\text { Aktiva lancar }}{\text { Hutang lancar }}
$$

Debt Equity Ratio ini menunjukkan bagaimana kemampuan perusahaan menggunakan modal yang adal dalam memenuhi kewajiban (Famiah, 2016), rumus Debt Equity Ratio:

$$
\text { DER }=\frac{\text { Total hutang }}{\text { Total ekuitas }}
$$


Total Asset Turnover merupakan rasio yang digunakan untuk mengukur perputaran aset perusahaan dengan jumlah penjualan yang diperoleh (Famiah, 2016), rumus Total Asset Turnover:

$$
\text { TATO }=\frac{\text { penjualan }}{\text { total aset }}
$$

\section{Uji Kualitas Data}

Pengujian kualitas data dengan menggunakan analisis statistik deskriptif dan uji asumsi klasik. Analisis statistik deskriptif digunakan untuk melihat tabel statistik yang hasilnya akan menunjukkan pengukuran mean, nilai minimal, nilai maksimal, dan standar deviasi pada semua variabel. Sedangkan uji asumsi klasik ini meliputi 4 pengujian yaitu yang pertama uji normalitas digunakan untuk menguji apakah model regresi berdistribusi normal atau tidak, yang kedua uji multikolinearitas digunakan untuk menguji apakah dalam model regresi terdapat korelasi antara variabel bebas, yang ketiga yaitu uji heteroskedastisitas digunakan untuk menguji apakah dalam model regresi terjadi ketidaksamaan variance dari residual satu pengamatan ke pengamatan yang lainnya, yang keempat uji autokorelasi digunakan untuk menguji apakah dalam model regresi terdapat korelasi antara kesalahan pengganggu pada periode ke t dengan kesalahan pengganggu pada periode t-1 (Januardin, Simatupang, Wulandari, Meliana, \& Alfarisi, 2020).

Pengujian hipotesis yaitu uji t dan uji f, pengujian hipotesis uji t yaitu dilakukan secara parsial bertujuan untuk mengetahui pengaruh dari masing-masing variabel independen terhadap variabel dependen. Sedangkan uji f yaitu uji secara simultan untuk menguji variabel independen secara bersamasama terhadap variabel dependen. Teknik analisis data menggunakan analisis regresi linier berganda yaitu model regresi yang variabel ndependennya merupakan fungsi linier dari beberapa variabel bebas, regresi ini bermanfaat untuk meneliti pengaruh beberapa variabel yang berkorelasi dengan variabel yang diuji. Adapun pengujian koefisien determinasi untuk mengetahui seberapa pengaruh variabel bebas terhadap variabel terikat.

\section{HASIL DAN PEMBAHASAN}

\section{Analisis Statistik Deskriptif}

Statistik deskriptif memberikan gambaran mengenai data yang diperoleh dari hasil penelitian. Hasil perhitungan statistik deskriptif ditunjukkan pada:

Tabel 1

Descriptive Statistics

\begin{tabular}{llllll}
\hline & $\mathrm{N}$ & Minimum & Maximum & Mean & Std. Deviation \\
\hline X1 & 40 &, 61 & 4,89 & 2,1690 & 1,25834 \\
X2 & 40 &, 15 & 2,91 &, 8050 &, 70094 \\
X3 & 40 &, 50 & 2,39 & 1,0598 &, 51925 \\
Y & 40 & 9,37 & 60,89 & 27,0550 & 13,32650 \\
Valid N & 40 & & & & \\
(listwise) & & & & & \\
\hline
\end{tabular}

Berdasarkan tabel diatas menujukkan bahwa jumlah data $(\mathrm{N})$ adalah 40 data/observasi dengan variabel dependennya price earning ratio. Dari hasil price earning ratio memiliki nilai rata-rata sebesar 27,0550. Nilai tertinggi price earning ratio sebesar 60,89 diperoleh pada perusahaan Unilever Indonesia Tbk (UNVR) tahun 2017, dan nilai terendah sebesar 9,37 diperoleh pada perusahaan Gudang Garam Tbk (GGRM) tahun 2019. Sehingga hasil tersebut menunjukkan bahwa besarnya price earning ratio perusahaan manufaktur yang terdaftar dalam indeks LQ 45 yang menjadi sampel dalam penelitian ini berkisar antara 9,37 sampai 60,89. Sedangkan standar deviasi sebesar 13,32650 yang artinya terjadi penyimpangan nilai price earning ratio terhadap nilai rata-ratanya sebesar 13,32650.

Variabel current ratio memiliki nilai mean 2,1690 artinya nilai rata-rata current ratio selama periode penelitian sebesar 2,1690, nilai tertinggi CR sebesar 4,89 diperoleh pada perusahaan Indocement Tunggal Perkasa Tbk (INTP) tahun 2015, nilai terendah CR sebesar 0,61 terdapat pada perusahaan Unilever Indonesia Tbk (UNVR) tahun 2016 dengan standar deviasi 1,25834 artinya kemampuan perusahaan dalam membayar hutang lancar yang dimiliki selama periode penelitian sebesar 0,8050 . 
Variabel debt to equity ratio memiliki nilai mean sebesar 0,8050 artinya nilai rata-rata debt to equity ratio selama periode penelitian sebesar 0,8050. Nilai tertinggi DER sebesar 2,91 terdapat pada perusahaan Unilever Indonesia Tbk (UNVR) tahun 2019, sedangkan nilai terendah DER sebesar 0,15 terdapat pada perusahaan Indocement Tunggal Perkasa Tbk (INTP) tahun 2016 dengan standar deviasi sebesar 0,70094 artinya kemampuan perusahaan dalam melunasi hutang dari ekuitas yang dimiliki selama periode penelitian sebesar 0,70094, dan untuk variabel total asset turnover nilai mean 1,0598 artinya nilai rata-rata total asset turnover selama periode penelitian sebesar 1,0598. Nilai tertingginya sebesar 2,39 terdapat pada perusahaan Unilever Indonesia Tbk (UNVR) tahun 2016, sedangkan nilai terendahnya sebesar 0,50 terdapat pada perusahaan Indocement Tunggal Perkasa Tbk (INTP) tahun 2017 dengan standar deviasi sebesar 0,51925 artinya kemampuan aset perusahaan untuk memperoleh pendapatan selama periode penelitian sebesar 0,51925.

\section{Uji Normalitas}

Tabel 2

One-Sample Kolmogorov-Smirnov Test

\begin{tabular}{llr}
\hline & & $\begin{array}{c}\text { Unstandardize } \\
\text { d Residual }\end{array}$ \\
\hline $\mathrm{N}$ & Mean & 39 \\
Normal Parameters ${ }^{a, b}$ & Std. Deviation & 9,94096221 \\
& Absolute &, 216 \\
Most Extreme & Positive &, 216 \\
Differences & Negative &,- 143 \\
Kolmogorov-Smirnov $Z$ & & 1,348 \\
Asymp. Sig. (2-tailed) & &, 053 \\
\hline
\end{tabular}

Berdasarkan tabel diatas, hasil uji kolmogorov-smirnov menujukkan bahwa nilai signifikansinya sebesar 0,053 yang artinya nilai tersebut $>0,05$, maka dapat disimpulkan bahwa data berdistribusi dengan normal.

\section{Uji Multikolinearitas}

Tabel 3

\begin{tabular}{llrr}
\multicolumn{4}{c}{ Coefficients $^{\mathbf{a}}$} \\
\hline Model & \multicolumn{3}{c}{ Collinearity Statistics } \\
& & Tolerance & VIF \\
\hline \multirow{3}{*}{1} & CR &, 502 & 1,991 \\
& DER &, 314 & 3,187 \\
& TATO &, 529 & 1,892 \\
\hline
\end{tabular}

a. Dependent Variable: PER

Dari hasil uji multikolinearitas menunjukkan bahwa variabel independen memiliki nilai tolerance $>0,10$ dan nilai VIF $>10$ sehingga dapat disimpulkan bahwa tidak terjadi autokorelasi antar variabel independen sehingga penelitian ini tidak ada masalah multikolinearitas.

\section{Uji Heteroskedastisitas}

Tabel 4

\begin{tabular}{|c|c|c|c|c|c|c|}
\hline \multicolumn{7}{|c|}{ Coefficients $^{\mathbf{a}}$} \\
\hline \multirow[t]{2}{*}{ Model } & & \multicolumn{2}{|c|}{ Unstandardized Coefficients } & \multirow{2}{*}{$\begin{array}{l}\text { Standardized } \\
\text { Coefficients } \\
\text { Beta } \\
\end{array}$} & \multirow[t]{2}{*}{$\mathrm{t}$} & \multirow[t]{2}{*}{ Sig. } \\
\hline & & $\bar{B}$ & Std. Error & & & \\
\hline \multirow{4}{*}{1} & (Constant) & 5,976 & 4,061 & & 1,471 &, 150 \\
\hline & $\mathrm{CR}$ & 1,489 & 1,735 & ,199 &, 858 & ,397 \\
\hline & DER & 3,644 & 3,952 & 271 & 922 &, 363 \\
\hline & TATO & $-4,998$ & 4,037 &,- 281 & $-1,238$ & ,224 \\
\hline
\end{tabular}


Berdasarkan tabel diatas, uji heteroskedastisitas dengan metode uji glejser menunjukkan bahwa semua variabel bebas memiiki nilai signifikansi > 0,05 maka dapat disimpulkasn bahwa tidak terjadi heteroskedastisitas.

\section{Uji Autokorelasi}

\section{Tabel 5}

\begin{tabular}{lr}
\multicolumn{2}{c}{ Runs Test } \\
\hline & $\begin{array}{l}\text { Unstandardize } \\
\text { d Residual }\end{array}$ \\
\hline Test Value $^{a}$ & $-2,68370$ \\
Cases $<$ Test Value & 19 \\
Cases $>=$ Test Value & 20 \\
Total Cases & 39 \\
Number of Runs & 16 \\
$Z$ & $-1,295$ \\
Asymp. Sig. (2- &, 195 \\
tailed) & \\
\hline T.
\end{tabular}

Berdasarkan hasil uji auttokorelasi dengan metode runs test diperoleh nilai asymp. Sig (2-tailed) sebesar 0,195, yang artinya nilai tersebut lebih besar dari 0,05. Sehingga dapat disimpulkan bahwa data pada penelitian ini bebas dari masalah autokorelasi.

\section{Analisis Regresi Linier Berganda}

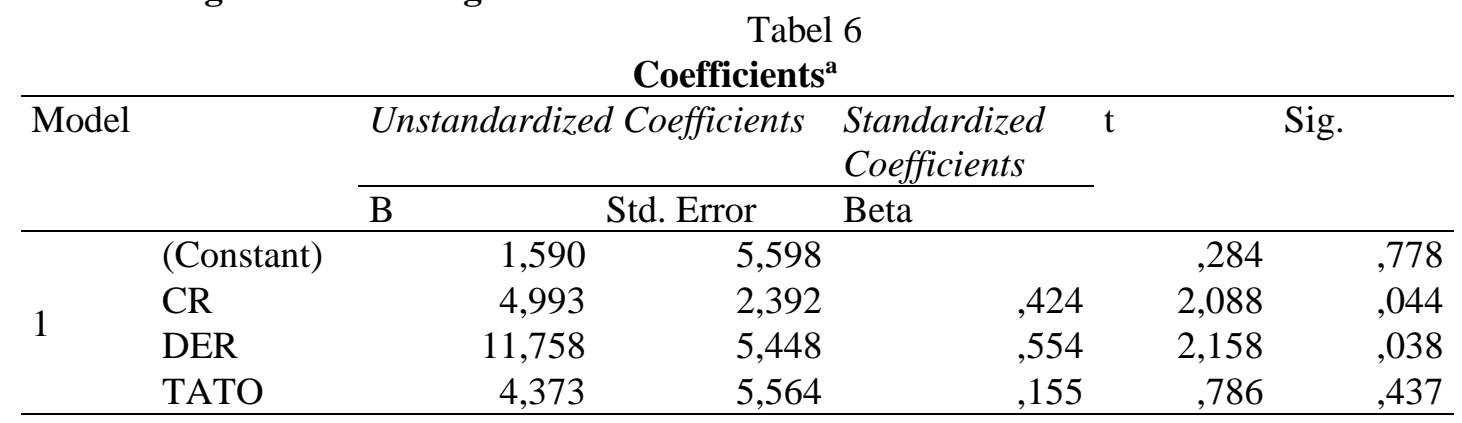

a. Dependent Variable: PER

Persamaan garis regresi sebagai berikut:

$\mathrm{Y}=1,590+4,993 \mathrm{CR}+11,758 \mathrm{DER}+4,373 \mathrm{TATO}+\mathrm{e}$

Dari persamaan tersebut, dapat dijelaskan sebagai berikut:

1. Konstanta sebesar 1,590 artinya jika semua variabel independen niilainya sama dengan nol, maka besarnya price earning ratio adalah 1,590.

2. Koefisien variabel current ratio sebesar 4,993 artinya jika nilai variabel independen lainnya tetap dan CR mengalami kenaikan sebesar 1, maka price earning ratio akan meningkat sebesar 4,993.

3. Koefisien variabel debt to equity ratio sebesar 11,758 artinya jika nilai variabel independen lainnya tetap dan DER mengalami kenaikan sebesar 1, maka price earning ratio akan meningkat sebesar 11,758 .

4. Koefisien variabel total asset turnover sebesar 4,373 artinya jika nilai variabel independen lainnya tetap dan TATO mengalami kenaikan sebesar 1, maka price earning ratio akan meningkat sebesar 4,373 .

\section{Uji Hipotesis Parsial (Uji t)}

1. Variabel CR memiliki nilai t hitung 2,088 $>\mathrm{t}$ tabel 1,6883 dengan nilai signifikansi $0,044<0,05$ menunjukkan bahwa variabel CR berpengaruh positif dan signifikan terhadap PER.

2. Variabel DER memiliki nilai $\mathrm{t}$ hitung 2,158 > t tabel dengan nilai signifikansi 0,038<0,05 menunjukkan bahwa variabel DER berpengaruh positif dan signifikan terhadap PER.

3. Variabel TATO memiliki nilai t hitung $0,786<\mathrm{t}$ tabel dengan nilai signifikansi $0,437<0,05$ menunjukkan bahwa variabel TATO tidak berpengaruh signifikan terhadap PER. 
Tabel 7

Uji Hipotesis Simultan (Uji f)

\begin{tabular}{lllllll}
\hline Model & & $\begin{array}{l}\text { Sum of } \\
\text { Squares }\end{array}$ & df & $\begin{array}{l}\text { Mean } \\
\text { Square }\end{array}$ & F & Sig. \\
\hline \multirow{4}{*}{1} & Regression & 1431,252 & 3 & 477,084 & 4,447 & ,009 \\
& Residual & 3755,264 & 35 & 107,293 & & \\
& Total & 5186,515 & 38 & & & \\
\hline
\end{tabular}

Berdasarkan tabel diatas diperoleh $\mathrm{F}$ hitung sebesae 4,447 > 2,87 dengan nilai signifikansinya $0,009<0,05$ artinya current ratio, debt to equity ratio, dan total asset turnover secara simultan berpengaruh signifikan terhadap price earning ratio.

\section{Koefisien Determinasi}

Tabel 8

Model Summary

\begin{tabular}{|c|c|c|c|c|}
\hline Model $\mathrm{R}$ & & R Square & $\begin{array}{l}\text { Adjusted R } \\
\text { Square }\end{array}$ & $\begin{array}{l}\text { Std. Error of } \\
\text { the Estimate }\end{array}$ \\
\hline 1 &, $525^{\mathrm{a}}$ & 276 & ,214 & 10,35825 \\
\hline
\end{tabular}

a. Predictors: (Constant), TATO, CR, DER

Berdasarkan tabel diatas, diperoleh nilai adjusted $R$ square sebesar 0,214 artinya price earning ratio dipengaruhi oleh current ratio, debt to equity ratio, dan total asset turnover sebesar $21,4 \%$ sedangkan sisanya $(100 \%-21,4 \%=78,6 \%)$ dipengaruhi oleh variabel lain di luar penelitian ini.

\section{PEMBAHASAN}

Variabel current ratio berpengaruh terhadap price earning ratio pada perusahaan manufaktur yang terdaftar dalam indeks LQ 45 periode 2015-2019. Current ratio yang tinggi berarti perusahaan dalam kondisi baik sehingga meningkatkan kepercayaan investor untuk membeli saham, semakin likuid suatu perusahaan maka investor akan cenderung membeli saham karena perkiraan laba yang diperoleh cukup tinggi sehingga current ratio berpengaruh terhadap price earning ratio. Hal ini sesuai dengan penelitian dari Susanti et al. (2017) dan Aulia (2013), namun berbeda dengan penelitian dari Batubara et al. (2019) dan Mendra (2016) yang menunjukkan bahwaa current ratio tidak signifikan terhadap price earning ratio.

Variabel debt to equity ratio berpengaruh positif dan signifikan terhadap price earning ratio, menurut teori MM tentang pajak yang dikemukakan oleh Modigliani dan Miller dalam Famiah (2016), dalam penelitian tersebut menyatakan bahwa dengan menggunakan hutang yang tinggi akan meningkatkan nilai perusahaan karena dapat menghemat pengeluaran pajak. Sehingga DER berpengaruh positif signifikan terhadap PER, hal ini sesuai dengan penelitian dari Famiah (2016) dan Mulyani \& Pitaloka (2017) namun berbeda dengan penelitian dari Wahyuni et al. (2020) yang menyatakan bahwa DER negatif tidak signifikan terhada PER.

Variabel total asset turnover tidak berpengaruh terhadap price earning ratio dikarenakan perusahaan kurang mampu memanfaatkan aktivanya dalam menciptakan penjualan sehingga akan mengurangi efektivitas perusahaan dalam memanfaatkan sumber daya dan kurang mampu menjaga perputaran aset secara efisien. Hal ini sesuai dengan penelitian dari Melati (2011), Massie (2015) dan Mendra (2016), namun berbeda dengan penelitian dari Famiah (2016) yang menyatakan bahwa TATO berpengaruh terhadap PER.

Variabel current ratio, debt to equity ratio, dan total asset turnover secara simultan berpengaruh signifikan terhadap price earning ratio hal ini sesuai dengan penelitian dari Susanti et al. (2017).

\section{KESIMPULAN}

Current ratio dan Debt to equity ratio berpengaruh positif dan signifikan terhadap price earning ratio pada perusahaan manufaktur yang terdaaftar dalam indeks LQ 45 periode 2015-2019. Sehingga jika current ratio dan debt to equity ratio naik, maka price earning ratio juga mengalami kenaikan. Total asset turnover tidak berpengaruh signifikan terhadap price earning ratio pada perusahaan manufaktur yang terdaftar dalam indeks LQ 45 periode 2015-2019, sehingga jika nilai TATO 
mengalami perubahan itu tidak akan memepengaruhi nilai pada price earning ratio. Current ratio, debt to equity ratio, dan total asset turnover secara simultan berpengaruh signifikan terhadap price earning ratio.

\section{Saran}

Berdasarkan kesimpulan diatas, saran yang dapat diberikan yaitu:

1. Secara teoritis terkait dengan penelitian selanjutnya untuk memperbesar populasinya, menggunakan populasi seluruh perusahaan manufaktur yang terdaftar di BEI sehingga tidak hanya tertuju pada satu indeks saja dan bisa menambah minimal satu variabel baru yang belum ada di penelitian ini misalnya variabel return on asset atau yang lainnya agar penelitian lebih akurat, dikarenakan penelitian ini hanya menggunakan perusahaan manufaktur yang terdaftar secara berturut-turut dalam Indeks LQ 45 pada tahun 2015-2019, sehingga data yang diambil ada kemungkinan kurang mencerminkan perusahaan dalam jangka waktu yang panjang. Penelitian ini juga terbatas pada pengujian mengenai beberapa faktor yang mempengaruhi price earning ratio, ada banyak hal yang mempengaruhi price earning ratio namun dalam penelitian ini hanya melibatkan 3 variabel independen yaitu current ratio, debt to equity ratio, dan total asset turnover.

2. Secara praktis terkait para investor yang akan mengambil keputusan berinvestasi hendaknya lebih memperhatikan variabel current ratio dan debt to equity ratio dikarenakan dua variabel tersebut mempengaruhi PER yang digunakan untuk pengambilan keputusan investasi. Dan bagi perusahaan hendaknya lebih meningkaatkan kemampuan dalam menghasilkan laba dengan cara mengefektifkan penggunaan biaya sehingga meningkatkan laba bersih kepada investor, jadi investor akan tertarik kepada perusahaan.

\section{REFERENSI}

Affinanda, A., \& Yuyetta, E. N. A. (2015). Analisis Pengaruh Rasio Keuangan Terhadap Return Saham Perusahaan dalam Indeks LQ 45 Tahun 2010-2013. Diponegoro Journal of Accounting, $4(2), 1-11$.

Aulia, N. S. (2013). Pengaruh Current Ratio, Leverage, dan Return On Equity Terhadap Price Earning Ratio Pada Perusahaan Paper And Allied Products Yang Terdaftar Di BEI. 4(2).

Batubara, H. C., Astuti, D. N., \& Ramadani. (2019). Pengaruh Current Ratio dan Return On Equity Terhadap Price Earning Ratio Pada Perusahaan Manufaktur Sub Sektor Makanan dan Minuman yang Terdaftar Di Bursa Efek Indnesia (BEI) Periode 2013-2017. 2.

Diana, T. (2019). Pegaruh Likuiditas dan Profitabilitas Terhadap Price Earning Ratio pada PT Indofood Sukses Makmur Tbk. 4(2), 17-25.

Famiah, R. (2016). Pengaruh Return n Equity (ROE), Debt to Equity Ratio (DER), dan Total Asset Turnover (TATO) Terhadap Price Earning Ratio (PER). 65(1), 46-54.

Handayani, H. (2018). Pengaruh Current Ratio, Debt t Equity Ratio, Return On Equity dan Price Book Value Terhadap Price Earning Ratio pada Perusahaan Food \& Beverages yang Terdaftar di Bursa Efek Indonesia Periode 2011-2017. 1-16.

Haryani, S., \& Priantinah, D. (2018). Pengaruh Inflasi, Nilai Tukar Rupiah/Dolar As, Tingkat Suku Bunga Bi, Der, Roa, Cr Dan Npm Terhadap Return Saham. Nominal, Barometer Riset Akuntansi Dan Manajemen, 7(2). https://doi.org/10.21831/nominal.v7i2.21353

Houmes, R., \& Chira, I. (2015). The effect of ownership structure on the price earnings ratio - returns anomaly. International Review of Financial Analysis, 37, 140-147. https://doi.org/10.1016/j.irfa.2014.11.017

Januardin, Simatupang, I., Wulandari, S., Meliana, I. A., \& Alfarisi, M. (2020). Pengaruh DER , NPM , dan PER terhadap Return Saham pada Perusahaan Sektor Property and Real Estate di Bursa Efek Indonesia. 4, 423-434.

Massie, J. Y. (2015). Analisis Pengaruh Total Asset Turnover, Return On Equity, dan Dividen Payout Ratio terhadap Price Earning Ratio Pada Perusahaan Manufaktur Yang Terdaftar Di BEI Tahun 2011-2013. 
Melati, S. M. (2011). Analisis Faktor-Faktor Yang Mempengaruhi Price Earning Ratio (Studi Empiris pada Perusahaan Manufaktur di Bursa Efek Indonesia).

Mendra, N. P. Y. (2016). Pengaruh Rasio Keuangan Terhadap Perubahan Laba Pada Perusahaan Manufaktur Yang Terdaftar di BEI Tahun 2008-2011. Jurnal Ekonomi Dan Bisnis, 1(1), 60-77.

Mulyani, \& Pitaloka. (2017). Pengaruh Return on Equity, Earning per Share ( EPS ), dan Debt to Equity Ratio terhadap Price Earning Ratio ( PER ) Pada PT Indofood Sukses. 4(1).

Oktaviasari, W. M. E. I. (2017). Pengaruh Leverage, Return On Equity, Size, dan Current Ratio terhadap Price Earning Ratio pada Perusahaan Sektor Industri Barang Konsumsi yang Terdaftar di Bursa Efek Indnesia (BEI) Periode 2013-2015. 01(10), 1-17.

Sihaloho, S. (2020). Analisis Pengaruh Rasio Likuiditas, Rasio Aktivitas, Rasio Solvabilitas dan Rasio Profitabilitas terhadap Price Earning Ratio pada Perusahaan Manufaktur yang Terdaftar di Bursa Efek Indonesia Tahun 2011-2016. 4(2), 132-145.

Sijabat, F. D. (2018). Pengaruh DPR, DER, ROA, dan ROA terhadap Price Earning Ratio Pada Perusahaan Manufaktur. Manajemen Unud, 7(7), 3681-3708.

Supriati, D. (2018). Pengaruh Profitabilitas, Likuiditas, Leverage, Dan Ukuran Perusahaan Terhadap Price Earning Ratio Pada Perusahaan Manufaktur Yang Listing Di Bursa Efek Indonesia. 14(01), 1-22.

Susanti, O., Qomari, N., \& Negoro, B. K. (2017). Pengaruh Current Ratio, Debt to Equity Ratio dan Total Assets Turnover terhadap Price Earning Ratio pada Perusahaan PT. SUPARMA, TBK. 4(2), 238-248.

Wahyuni, I., Susanto, A., \& Asakdiyah, S. (2020). Pengaruh Debt To Equity Ratio, Current Ratio, Return On Equity, dan Net Profit Margin Terhadap Price Earning ratio Perusahaan Sub Sektor Perkebunan Yang Terdaftar Pada Bursa Efek Indonesia Periode Tahun 2014-2017. 19(1), 7586.

Yulia. (2016). Analisis Pengaruh Rasio Likuiditas Terhadap Return Saham. IOSR Journal of Economics and Finance, 3(1), 1-217. https://doi.org/https://doi.org/10.3929/ethz-b-000238666 